\title{
Vermiwash: An effective nutritive boon to foliage and crops
}

\author{
Manpreet Kaur* and Devinder Pal Kaur \\ Department of Zoology, Khalsa College for Women, Civil Lines, Ludhiana (Punjab), INDIA \\ Corresponding author. E-mail: manpritsaini00088@gmail.com
}

Received: August 2, 2016; Revised received: February 18, 2017; Accepted: August 6, 2017

\begin{abstract}
Earthworms are often known as soil scientist. They are the main driving force that helps in sustainable production of food. They maintain the soil's physical, chemical and biological health and act as a bio fertiliser. Their excreta and body fluids (vermiwash) has a significant effect in promoting the growth of the agricultural plants. The shoot length, root length, number of twigs, flowers, fruit, grains and biomass, were increased significantly in all the plants that were treated with this biofertilizer. The analysis of the wash showed the high content of various macro and micro nutrients like $\mathrm{Ca}, \mathrm{K}, \mathrm{P}, \mathrm{S}$, organic carbon, $\mathrm{Zn}, \mathrm{Mn}, \mathrm{Cu}, \mathrm{Fe}$ etc. It also helps the plants for attainment of maturity and reproduction at faster rate, thus reducing the 'life-cycle' of crops and shortening their 'harvesting time'. So, it can be concluded there is significant increase in vermicompost treated plants as there is reduction in the incidence of 'pest and disease attack', and we can now control pests without pesticides' and 'now we can have a better taste of chemical-free organic food products.
\end{abstract}

Keywords: Agricultural plants, Bio-fertilizer, Soil micronutrients, Vermiwash

\section{INTRODUCTION}

\section{Earthworms}

Soil managers: Earthworms are also categorised as 'biological indicator' of soil fertility and 'soil conditioner'. They help in the improvement of the physical nature (soil porosity and tenderness), chemical nature (good $\mathrm{pH}$ and essential plant nutrients) and biological nature (beneficial soil microbes and organisms) and quality of soil where they inhabit. They eat away a large amount of soil with organic matter like microbes, plant and animal debris and grind them in their gizzard and digest them in their intestine with the help of various enzymes microbes (Scheu, 1987). The excretory material consists of 'vermicastings' which is rich in NKP (nitrates, phosphates and potash), micronutrients and beneficial soil microbes. Vermiculure is now replacing the highly destructive agro chemical industries with the organic one. They place an accountable role in converting the common soil into the fertile soil. They helps in promotion of soil fragmentation and aeration, and bring about 'soil turning' and dispersion in farmlands. Their activity in soil can also increase air-soil volume from $8-30 \%$. One acre of land can consists upto 3 million earthworms the activities of which can bring up to 8-10 tons of 'top soil' to the surface (in the form of vermicast) every year (Scheu, 1987). The Presence of these worms helps in regeneration of compacted soils and improves the water penetration in such soils by over 50\%. (Capowiez et al., 2009).

Vermiwash: Vermiwash, is liquid organic manure, is an aqueous extract of a column of freshly formed vermicompost and surface washings of earthworms. It is very useful as a foliar spray for plants as it contains the beneficial microorganisms, and water soluble fractions of nutrient substances (Ismail, 1997). The nutrients that are present in vermiwash are water-soluble and immediate requirements from a number of components can be met from a single source. In vermiwash, there is collection of excretory product and mucus secretion of earthworms along with micronutrients from the soil organic molecules. These nutrients are then transported to the aerial parts such as leaf, shoots and other parts of the plants in the natural ecosystem. Vermiwash, is basically a clear, transparent and pale yellow coloured fluid. It consists of various excretory products and secretions of earthworms and beneficial micronutrients from soil organic molecule (Ismail, 1997)). Vermiwash contains high quantities of nitrogen, phosphorus, potash, calcium, magnesium zinc and are alkaline in nature. Freshly collected vermiwash contains many beneficial microbes that promotes the plant growth and prevents infections. The Hormones that promotes the plant growth like indole acetic acid, gibberellic acid etc are also present. The vermiwash must be diluted before its application on the plants. It is one of the most cost efficient and environmentally friendly methods of waste disposal (Jayashree, 2006).) Principle: The principle of Vermi wash is based on the worm treated soils have burrows infested by the earthworms. The micro organisms like bacteria inhabit these burrows, and are known as the drilospheres. The water passing in these burrows gets enriched with the nutrients which later on get absorbed by the plants. 
This principle is applied for the preparation of vermiwash. Vermiwash can be produced by allowing water to percolate through the burrows made by the earthworms with the substrate like coconut leaf - cow dung kept in a plastic barrel. Thenafter, the water is collected in the vermicomposting system in which water in collected dropwise from a pot hung above the barrel into the. Vermiwash units can be set up either in barrels or in buckets or even in small earthen pots (Munroe, 2004).

Vermiwash unit: The unit of vermiwash can be set up in a plastic or iron barrel of 200 litre capacity. With this a hole is drilled on one side and a vertical limb of a $\mathrm{T}$ joint tube is joined in such a way that half to one inch of the tube projects inside the barrel. At one end a tap is attached to the horizontal limb while the other end is closed with a dummy nut. In this way the vermin set up is mounted on a suitable pedestal. The tap should be kept open, after that the layer of broken bricks or pebbles are filled uptill $25-30 \mathrm{~cm}$ inside of the barrel. The water is then allowed to flow through this layer, followed by $20-30 \mathrm{~cm}$ layer of coarse sand and good loamy soil which is of 30-45 cm layer and is kept moistened. Different species of earthworms namely Eisenia foetida, E.enginiae anecics and lumbricus terrestris are introduced into the unit. Cattle dung pats, dry leaves, straw and hay are placed on top of this layer of soil. The unit needs to be moistened daily (Edwards, 1988).

Wash collection: The tap is closed and water is sprinkled on top of the vermin unit. After sprinkling the water starts percolating through the compost and carries with itself the essential nutrients. The tap is then opened on the next day for the collection of the wash then it is sprayed on plants as a foliar or sprays. The

Table 1.Chemical composition of vermiwash (Efresh, 2012).

\begin{tabular}{ll}
\hline Organic Carbon \% & $0.008 \pm 0.001$ \\
Electroconductivity dS/m & $0.25 \pm 0.03$ \\
Ph & $7.48 \pm 0.030$ \\
Total Kjeldhal Nitrogen \% & $0.01 \pm 0.005$ \\
Available Phosphate \% & $1.69 \pm 0.05$ \\
Calcium (ppm) & $3 \pm 1$ \\
Sodium (ppm) & $8 \pm 1$ \\
Potassium (ppm) & $25 \pm 2$ \\
Copper (ppm) & $0.01 \pm 0.001$ \\
Ferrous (ppm) & $0.06 \pm 0.001$ \\
Manganese (ppm) & $0.58 \pm 0.040$ \\
Zinc (ppm) & $0.02 \pm 0.001$ \\
Magnesium (ppm) & $158.44 \pm 23.42$ \\
Total Fungi (CFU/ml) & $1.46 \pm 103$ \\
Nitrobacter (CFU/ml) & $1.12 \pm 103$ \\
Nitrosomonas (CFU/ml) & $1.01 \pm 103$ \\
Total Heterotrophs (CFU/ml) & $1.79 \pm 103$ \\
\hline
\end{tabular}

casting on the unit can be cleared periodically. Vermiwash can be collected and stored or diluted before use. It can be diluted with water $(10 \%)$ before spraying effectively on any plant or foliage. It should be diluted with water upto 5 to 10 times and then be applied. It can be mixed with urine of cow and then it is diluted for the use as foliar spray and pesticide. It is basically 1 litre of vermiwash and 1 litre of cow's urine and 8 litres of the water which forms an effective pesticide (Efresh, 2012)

\section{Dosage for use}

Root dip/stem dip: The seedlings of the plants are dipped in vermiwash solution for 15-20 minutes before transplantation. The solution needs to be diluted 5 times with water and then after they can be transplanted. In this way the cuttings of plants can also be dipped in the solution.

Foliar spray: The Vermiwash is diluted with water for 5 times and then sprayed on the crops. It enriches the soil with nutrients and helps in controlling plant disease.

Soil drench: Vermiwash is diluted about 10 times with water and the soil is drenched with the solution to prevent some of the soil borne pathogens as it as anti microbial properties.

Some studies of vermiwash as liquid fertilizer for agricultural use: Vermi wash is a brownish-red liquid which comes from the body of earthworms (as worm's body contain plenty of water) and is rich in vitamins, amino acids, nutrients like nitrogen, magnesium, potassium, copper, zinc, calcium, iron and growth hormones like 'auxins', 'cytokinins. It also consists of plenty of nitrogen fixing and phosphate solubilising bacteria (nitrosomonas, nitrobacter and actinomycetes). It has significant 'growth promoting' as well as 'pest killing' properties. Studies reported that increase in yield of radish by $7.3 \%$ on weekly application of vermiwash (Giraddi, 2003). It is also reported that both growth and yield of paddy gets significantly increased with application of vermicast and vermiwash extracts (Thangavel et al., 2003). Farmers of Bihar in North India also reported that the growth enhancing and pesticidal, anti microbial properties of the liquid washes. They applied it on brinjal and tomato plants and yielded excellent results with healthy and bigger fruits. (Saumaya et at., 2007) studied that the use of vermiwash on chilli for the control and management of 'Thrips' (Scirtothrips dorsalis) and 'Mites' (Polyphagotarsonemus latus). The wash was used in three different forms of dilutions e.g. by mixing it with water both as 'seedling dip' treatment or 'foliar spray' in 1:1, 1:2 and 1:4. The application of the resultant showed significantly lower incidence of thrips and mites attacks. It registered a low mean population of thrips and mites as 0.35 and 0.64 per leaf respectively and significantly maximum dry chilli 
Table 2. Summary of vermiwash as liquid fertilizer in agricultural use from different types of substrates.

\begin{tabular}{|c|c|c|c|}
\hline Substrate used for vermiwash & Plant & Findings & Reference \\
\hline leaf litter and Cow dung & Rice & $\begin{array}{l}\text { Studies showed leaf and root length was maximum, } \\
\text { leaves number and height of plants was recorded from } \\
\text { pots that were applied with vermicompost and vermi- } \\
\text { wash. }\end{array}$ & $\begin{array}{l}\text { Tharmaraj } \\
\text { et al., } 2011\end{array}$ \\
\hline Coconut leaf litter and Cow dung & $\begin{array}{lr}\text { Okra, } & \text { Cow- } \\
\text { pea } & \text { and } \\
\text { Maize } & \end{array}$ & $\begin{array}{l}\text { Vermiwash consists of high concentration of } \mathrm{K}, \mathrm{P}, \mathrm{Mg} \\
\text { and } \mathrm{Ca} \text {; from pure cow dung it showed the highest in } \mathrm{N}, \mathrm{P} \text {, } \\
\mathrm{Mg}, \mathrm{Ca} \text { and indoleacetic acid (IAA) concentration. } \\
\text { Seedling vigour index in Cowpea was maximum in 1:10 } \\
\text { dilution. }\end{array}$ & $\begin{array}{l}\text { Gopal } \\
\text { al., } 2010\end{array}$ \\
\hline Kitchen waste and Animal waste & & $\begin{array}{l}\text { Results showed bio-fertilizer serves as a great potential for } \\
\text { a nutrient deficient soil by using the combination of sub- } \\
\text { strate. }\end{array}$ & $\begin{array}{l}\text { Nath et al. } \\
2009\end{array}$ \\
\hline Cow manure & $\begin{array}{l}\text { Indian Bor- } \\
\text { age } \\
\text { (Plectranthu } \\
\text { sambionicus }\end{array}$ & $\begin{array}{l}\text { High potassium }(\mathrm{K}) \text { concentration was determined. } \\
\text { Diluted concentration of vermiwash }(10 \%) \text { showed the } \\
\text { highest germination percentage, shoot and root length, } \\
\text { total chlorophyll as well as carotenoids content. }\end{array}$ & $\begin{array}{l}\text { Quaik et } \\
\text { al., } 2012\end{array}$ \\
\hline
\end{tabular}

yield 2.98 quintal/ha. (Suthar, 2010) reported presence of hormone like substances in vermiwash. He studied its impact on various parameters like seed germination, shoot, root length in Cyamopsis tertagonoloba and compared it with urea solution $(0.05 \%)$. The germination was maximum in vermiwash $90 \%$ on $50 \%$ as compared to $61.7 \%$ in urea solution. The root and shoot length was also maximum i.e $8.65 \mathrm{~cm}$ and $12.42 \mathrm{~cm}$ on $100 \%$ vermiwash as compared to 5.87 and 7.73 with urea application.

\section{Conclusion}

Although chemically fertilized crops are recklessly used today, people are getting more aware about the effects of usage of these chemical fertilisers. These chemicals are raising an alarming health issues. So, organically cultured fruits and vegetables are in great demand. Vermiwash is a sustainable, non-toxic and environmentally friendly approach. The wash is a brownish-red liquid which both productive and protective in crop farming. This liquid partially comes from the earthworm's body(as the worm's body consist of plenty of water) and is rich source of amino acids, vitamins and nutrients like nitrogen, potassium, magnesium, zinc, calcium, copper and iron and growth hormones like 'auxins', 'cytokinins. It also consists of plenty of nitrogen fixing and phosphate solubilising bacteria (nitrosomonas, nitrobacter and actinomycetes). It also had positive impacts on flowering of horticultural crops and aids in fruit development and restores its natural fertility and maintain productivity. Vermiwash has great 'growth promoting' as well as 'pest killing' properties. It serves as a boon and its application in farming practices can also lead to significant increase in crop yield production.

\section{REFERENCES}

Capowiez, Y., Cadoux, S., Bouchand P., Roger-Estrade, J., Richard, G. and Boizard, H. (2009). Experimental evidence for the role of earthworms in compacted soil regeneration based on field observations and results from a semi-field experiment. Soil Biology \& Biochemistry, 41(4):711-717

Edwards, C.A. (1988) Breakdown of animal, vegetable and industrial organic waste by earthworms. Agric. Ecosyst. Environ 24: 21-31.

Efresh (2012). Vermiwash: A Plant Tonic for Earthworms Industry, Worm Digest. Retrieved from http:// www.efreshindia.com

Giraddi, R.S. (2003). Method of extraction of earthworm wash: A plant promoter substance. VIIth National Sympo-sium on Soil Biology and Ecology, Bangalore

Gopal M, Gupta A, Palaniswami C, Dhanapal R and George V Thomas (2010). Coconut leaf vermiwash: a bio-liquid from coconut leaf vermicompost for improving the crop production capacities of soil. Current Science, 98 (9):1202-10

Ismail, S.A. (1997). Vermicology: The Biology of Earthworms. Orient longman Press, Hyderabad

Jayashree, M.P. (2006). Vermiwash-The wonder tonic in agricultural. Kisan World, 6: 44.

Munroe, G. (2004). Manual of On-Farm Vermicomposting and Vermiculture, Retrieved from http:// www.allthingsorganic.ca/pdf/ Vermiculture_FarmersManual_gm.pdf

Nath G, Singh, K. and Singh, D.K. (2009). Chemical Analysis of Vermicomposts / Vermiwash of Different Combinations ofAnimal, Agro and Kitchen Wastes. Australian Journal of Basic and Applied Sciences 3(4): 36713676.pp: 92

Quaik S, Embrandiri A, Rupani P. F., Singh R. P. and Ibrahim, M. H. (2012). Effect of Vermiwash and Vermicomposting Leachate in Hydroponics Culture of Indian Borage (Plectranthus ambionicus) Plantlets. UMT 11th International Annual Symposium on Sustainability 
Manpreet Kaur and Devinder Pal Kaur / J. Appl. \& Nat. Sci. 9 (3): 1608 -1611 (2017)

Science and Management. a -ISBN 978-967-5366-93-2: 210-214

Saumaya, G, Giraddi, R.S. and Patil, R.H. (2007). Utility of vermiwash for the management of thrips and mites on chilli (capiscum annum) amended with soil organics. Karnataka Journal of Agriculture Sciences, 20(3):657-59

Scheu, S. (1987). Microbial activity and nutrient dynamics in earthworms casts. Journal of Biological Fertility Soils, 5(3):230-234

Suthar, S. (2010). Evidence of plant hormone like sub-stances in vermiwash: An ecologically safe option of synthetic chemicals for sustainable farming. Journal of Ecological Engineering, 36(8):1089-1092

Thangavel, P, Balagurunathan, R, Divakaran, J. and Prabhakaran, J. (2003). Effect of vermiwash and vermi-cast extract on soil nutrient status, growth and yield of paddy. Advances of Plant Sciences, 16(1):187-190

Tharmaraj, K., Ganesh, P., Kolanjinathan, K., Kumar, R. and Anandan, A. (2011). Influence of vermicompost and vermiwash on physic chemical properties of rice cultivated soil. Current Botany 2:18-21 